\title{
Sweet Mitochondria: A Shortcut to Alzheimer's Disease
}

\author{
Paula I. Moreira ${ }^{\mathrm{a}, \mathrm{b}, *}$ \\ ${ }^{a}$ CNC - Center for Neuroscience and Cell Biology, University of Coimbra, Coimbra, Portugal \\ ${ }^{\mathrm{b}}$ Faculty of Medicine, University of Coimbra, Coimbra, Portugal
}

Accepted 28 November 2017

\begin{abstract}
A growing body of evidence supports a clear association between Alzheimer's disease and diabetes and several mechanistic links have been revealed. This paper is mainly devoted to the discussion of the role of diabetes-associated mitochondrial defects in the pathogenesis of Alzheimer's disease. The research experience and views of the author on this subject will be highlighted.
\end{abstract}

Keywords: Alzheimer's disease, diabetes, mechanistic link, mitochondria

\section{INTRODUCTION}

Mitochondria are fascinating organelles. They are highly dynamic and plastic organelles and can adapt to different surroundings and particularities of each type of cell. Mitochondria are essential for the viability and proper function of cells, being involved in the generation of energy (ATP), metabolism of reactive oxygen species (ROS), buffering of cytoplasmic calcium $\left(\mathrm{Ca}^{2+}\right)$ and apoptosis [1], among other things. Considering neuronal cells, mitochondria are crucial for the maintenance of membrane ion gradients, and for neurotransmission and synaptic plasticity [2]. Taking into consideration that neurons are highly differentiated cells (cell body, dendrites, axons, and synaptic terminals) with a high metabolic rate that requires a constant supply of energy substrates (particularly glucose) and oxygen to survive, it is not surprising that alterations in mitochondria

\footnotetext{
${ }^{*}$ Correspondence to: Paula I. Moreira, Center for Neuroscience and Cell Biology, Rua Larga, Faculty of Medicine, Pólo 1, $1^{\text {st }}$ Floor, University of Coimbra, 3004-517 Coimbra, Portugal. Tel.: +351 239820 190; Fax: +351 239822 776; E-mails: pimoreira@fmed.uc.pt; venta@ci.uc.pt
}

will deeply impact the function and viability of neuronal cells. In fact, a delicate balance between mitochondrial fission, fusion, biogenesis, turnover, and transport must exist to ensure a healthy mitochondrial pool and, consequently, viable and healthy cells. This balance is lost in several diseases including Alzheimer's disease (AD) and diabetes [3-7]. AD is the most common cause of dementia in the elderly and despite the tremendous research efforts in the last decades, no cure or effective treatment exists [3]. Nevertheless, the mechanisms underlying AD pathophysiology have been successfully unveiled and accumulating evidence demonstrates the key involvement of mitochondrial anomalies in the development of the disease. The metabolic defects that characterize (sporadic) AD can be triggered or exacerbated by several risk factors including diabetes $[6,8]$.

Diabetes is a major public health problem that is reaching epidemic proportions around the world. It is a complex metabolic disorder mainly characterized by chronic hyperglycemia and associated with progressive end-organ damage. Besides the commonly associated chronic complications such as nephropathy, angiopathy, retinopathy, and peripheral 
neuropathy [9], it was also observed that people with diabetes perform poorly on cognitive tasks examining memory, attention, and verbal learning $[10,11]$. The long-term effects of diabetes on the brain are manifested at structural, neurophysiological, and neuropsychological level [12]. Although both type 1 diabetes (T1D) $[13,14]$ and type 2 diabetes (T2D) $[15,16]$ are associated with alterations in brain structure and function and increased risk of dementia [17], the association between $\mathrm{AD}$ and T2D is stronger than that with T1D. In fact, several lines of evidence demonstrate that T2D is associated not only with $\mathrm{AD}[15,18,19]$, but also with vascular dementia [19], Parkinson's disease [20], and Huntington's disease [21]. At the mechanistic level, it has been shown that mitochondrial defects play an important role in diabetes-associated brain alterations [8, $22,23]$ contributing to neurodegenerative events.

In this paper, I will present evidence from epidemiological and clinical studies that support a clear association between $\mathrm{AD}$ and diabetes. Then, the role of diabetes-induced mitochondrial defects as triggers and/or accelerators of AD (like) pathology will be discussed. The research experience and views of the author will be emphasized.

\section{EPIDEMIOLOGICAL AND CLINICAL STUDIES HAVE BOOSTED THE STUDY OF THE MECHANISTIC INTERRELATION BETWEEN DIABETES AND AD}

The effects of diabetes on the central nervous system (CNS) were described for the first time almost 100 years ago. In 1922, Miles and Root [24], reported that diabetic individuals perform poorly on cognitive tasks examining memory and attention. And, in 1950, Dejong named the diabetes-related CNS complications as diabetic encephalopathy [25]. Subsequent longitudinal and cross-sectional studies confirmed the negative impact of T1D [26-28] and T2D [29-32] on cognitive function. T2D has also been associated with 50\% increased risk of dementia [33]. Whether such an association is true for people T1D is not yet clear.

Over the past three decades, many epidemiological and clinical studies have shown a clear association between diabetes and an increased risk of developing AD. Our interest on the interrelation between diabetes and AD started shortly after the publication of the results of the Rotterdam Study [34, 35] showing that patients with T2D are at an increased risk to develop dementia and AD. Further evidence showed that individuals with T2D have nearly a twofold higher risk of AD than nondiabetic individuals [36-42]. Furthermore, the risk of $\mathrm{AD}$ associated with the APOE $\varepsilon 4$ allele has been suggested to be exacerbated by diabetes, as patients with diabetes who are $\varepsilon 4$ allele carriers are twofold more prone to develop AD than nondiabetic individuals who harbor the $\varepsilon 4$ allele [43]. Notably, a study of the Mayo Clinic Alzheimer Disease Patient Registry reported that greater than $80 \%$ of AD patients exhibit T2D or abnormal blood glucose levels [44], suggesting that $\mathrm{AD}$ patients are more vulnerable to T2D and the possibility of a linkage between the processes responsible for loss of brain and pancreatic $\beta$-cells in these disorders. However, it must be said that other studies did not find a clear link between $\mathrm{AD}$ and diabetes [45-47].

Considering the resemblances found between $\mathrm{AD}$ and T2D, and due to the lack of effective treatments for $\mathrm{AD}$, it has been hypothesized that anti-diabetic drugs can help treat AD patients. Promising effects of intranasally administered insulin or insulin analogues have been observed in $\mathrm{AD}$ and subjects suffering from amnestic mild cognitive impairment (MCI) [48-50], although insulin administration in APOE $\varepsilon 4$ carriers seems to exacerbate cognitive deficits [51]. Studies have also shown that the chronic treatment of diabetics with the antidiabetic agent metformin reduces the risk of cognitive decline [52]. However, conflicting effects of metformin treatment have been reported [53].

Thiazolidinediones (TZDs) are peroxisome proliferator-activated receptor- $\gamma$ (PPAR- $\gamma$ ) agonists and potent insulin sensitizers. Pioglitazone and rosiglitazone are the best characterized PPAR- $\gamma$ agonists. Rosiglitazone was associated with an early improvement of whole brain glucose metabolism, but not with any biological or clinical evidence for slowing progression over a 1-year follow up in the symptomatic stages of $\mathrm{AD}$ [54]. Mild and moderate $\mathrm{AD}$ patients who are $\mathrm{APOE} \varepsilon 4$ noncarriers treated with rosiglitazone during 6 months improved cognitive function, an effect not observed in APOE 44 carriers [55]. Also, a systemic review and meta-analysis concluded that pioglitazone may be useful in treating $\mathrm{AD}$ patients with comorbid diabetes [56]. A recent longitudinal study show that pioglitazone might provide a protective effect on dementia risk among individuals with T2D [57].

A recent prospective and observational study aimed at evaluating the effect of sitagliptin, a 
dipeptidyl peptidase-4 inhibitor (DPP-4I), on cognitive function of elderly diabetic patients with and without cognitive impairment revealed that elderly diabetic patients with and without $\mathrm{AD}$ treated with sitagliptin during 6 months show improved of cognitive function [58].

Concerning the effects of glucagon-like peptide-1 (GLP-1) analogues, a recent randomized, placebocontrolled, double-blind clinical trial involving 18 AD patients treated with the GLP-1 analogue liraglutide and $20 \mathrm{AD}$ patients treated with placebo revealed that treatment with liraglutide during 6 months prevented the decline of brain glucose metabolism [59]. More clinical trials are ongoing, namely a pilot clinic trial of exendin-4 in MCI and early stage AD subjects (NCT01255163) and a phase II clinical trial assessing the safety and efficacy of liraglutide in mild AD (NCT01843075).

The above evidence demonstrates that $\mathrm{AD}$ and diabetes are connected and instigated the research community to investigate the mechanisms linking both disorders.

\section{THE QUEST FOR THE MECHANISTIC LINKS BETWEEN AD AND DIABETES: A FOCUS ON DIABETES-RELATED MITOCHONDRIAL DEFECTS}

Based on a strong body of evidence demonstrating a clear connection between diabetes and $\mathrm{AD}$, several pre-clinical studies have been carried out in order to uncover the mechanistic basis of this connection. Several mechanisms shared by diabetes and AD have been identified, namely impaired insulin signaling, inflammation, the accumulation of advanced glycation end-products, oxidative stress, and mitochondrial dysfunction [7, 16, 22, 23, 60]. Here, I will discuss how diabetes-related brain mitochondrial anomalies contribute to cognitive defects and predispose to or exacerbate neurodegenerative events, particularly AD (like) pathology.

\section{Type 1 diabetes and AD (like) pathology}

Previous studies from our laboratory revealed that brain mitochondria isolated from streptozotocin (STZ)-induced diabetic rats present defects in the antioxidant system defenses, ATPase activity and ability to accumulate $\mathrm{Ca}^{2+}$ [61]. In accordance with our observations, others reported that brain mitochondria isolated from STZ-induced diabetic rats have a deficient respiratory chain $[62,63]$ that may con- tribute to oxidative and nitrosative injury of brain cells [64-66], tau hyperphosphorylation [65, 67, 68], amyloidogenesis $[69,70]$, and cognitive defects $[63$, $66,71,72]$. More recently, we observed that insulin treatment modulates mitochondrial dynamics and biogenesis, autophagy, and tau protein phosphorylation in the brain of STZ-induced diabetic rats [73].

Besides hyperglycemia, hypoglycemia, the most serious side effect associated to insulin therapy in T1D, also causes cognitive dysfunction $[74,75]$ in part by affecting mitochondria [76]. McGowan and collaborators [77] demonstrated that a mitochondrial substrate limitation following hypoglycemia increases mitochondrial free radical production in brain cortical mitochondria from newborn pigs. It was also shown that hypoglycemia in STZ-induced diabetic rats decreases mitochondrial respiratory chain efficiency [78]. Accordingly, we observed that insulin-induced acute hypoglycemia affects the antioxidant defenses of brain cortical mitochondria isolated from STZ-induced diabetic rats causing oxidative damage [79] and increasing the capacity of cortical synaptosomes to release excitatory amino acids [80]. Taking into consideration that mitochondria function is associated with neurotransmitters synthesis and release, our observations support the idea that mitochondrial dysfunction, oxidative stress, and excitatory neurotransmitters release are interconnected factors that may underlie the cognitive impairment observed in T1D patients under insulin therapy. Subsequent studies from our laboratory showed that recurrent hypoglycemia and long-term hyperglycemia affect the antioxidant defenses of brain cortical and hippocampal mitochondria contributing to oxidative stress [81]. Nevertheless, only hippocampal mitochondria showed altered efficiency of the respiratory chain and phosphorylation system affecting ATP production [81]. Similarly, Dave and collaborators [82] reported that recurrent hypoglycemia exacerbates cerebral ischemic damage in T1D rats through the increased generation of mitochondrial ROS.

Besides their effective antioxidant defense system, mitochondria have specific proteins that regulate the rate of ROS production named uncoupling proteins (UCPs). The dissociation of ATP production from ROS generation mediated by UCPs has been pointed as a key defensive mechanism against brain damage [83, 84]. In this line, we observed that recurrent episodes of hypoglycemia render brain cortical mitochondria more susceptible to UCPs-mediated uncoupling as compared 
with hyperglycemia [85] and the pharmacological inhibition of UCP2 exacerbates glucose fluctuationsmediated neuronal damage, namely mitochondria dysfunction and oxidative stress [86]. Interestingly, UCP2 gene variants have been associated with a reduced risk for diabetic neuropathy in T1D patients [87], suggesting that the increased expression of UCPs related to specific gene polymorphisms can limit neuronal death.

\section{Type 2 diabetes and AD (like) pathology}

An increased oxidative stress and mitochondrial dysfunction was observed in the Zucker diabetic fatty rat, a genetic model of T2D [88]. Accordingly, we found that brain vessels and synaptosomes from Goto-Kakizaki rats, a spontaneous model of non-obese T2D, present an age-dependent redox imbalance [89], which increases the vulnerability of brain structures to degenerative events. We also observed that T2D-like mice and triple transgenic AD mice $(3 \times T g-A D)$ present a similar profile of brain mitochondrial anomalies (defects in function, biogenesis, and turnover), redox imbalance, increased amyloid- $\beta$ (A $\beta)$ and phosphorylated tau levels, central and peripheral vascular alterations, and loss of synaptic integrity [90-93]. Accordingly, 3xTg-AD and T2D-like mice show similar behavioral and cognitive anomalies characterized by increased fear and anxiety and decreased learning and memory abilities [91]. Such findings prompted us to suggest that the metabolic alterations associated with diabetes contribute to AD-like pathologic features [90-92]. Accordingly, it was recently suggested that the higher hippocampal susceptibility to synaptic injury and cognitive dysfunction is linked to mitochondrial defects [94]. These authors observed that $\mathrm{db} / \mathrm{db}$ mice, a model of obese T2D, present altered brain mitochondrial morphology, reduced ATP production, and impaired mitochondrial complex I activity. These mitochondrial abnormalities seem to result from an imbalanced mitochondrial fusion and fission via a glycogen synthase kinase $3 \beta$ (GSK3 $\beta$ )/dynaminrelated protein-1 (Drp1)-dependent mechanism [94]. It was also reported that high glucose and $A \beta$ oligomers cause aberrant S-nitrosylation of insulindegrading enzyme and Drp1 inhibiting insulin and $A \beta$ catabolism as well as hyperactivating mitochondrial fission machinery, which results in dysfunctional synaptic plasticity and synapse loss [95]. A recent study from Petrov and collaborators [96] also showed that T2D induced by high fat diet affects brain mitochondrial function contributing to cognitive decline and $\mathrm{AD}$ pathology, which are ameliorated by the anti-diabetic drugs dipeptidylpeptidase-4 inhibitors [97] and metformin [98]. Also, the use of GLP-1 analogues (e.g., liraglutide and exendin-4) increase brain insulin, insulin-like growth factor 1, and GLP-1 signaling and decrease phosphorylated tau levels and apoptosis [99-102].

Using a rat model of sporadic AD induced by the intracerebroventricular (icv) administration of a subdiabetogenic dose of STZ (icvSTZ), a model firstly described by Hoyer's team [103-105], we found that the insulin-resistant brain state that characterizes the pathological course of the disease is accompanied by mitochondrial abnormalities [106]. We observed that icvSTZ promotes a significant decline in both brain cortical and hippocampal mitochondrial bioenergetics as reflected by impaired mitochondrial respiration and phosphorylation system, increased susceptibility to $\mathrm{Ca}^{2+}$-induced mitochondrial permeability transition pore opening, and oxidative stress. Importantly, increased levels of $A \beta$ and phosphorylated tau and cognitive defects accompanied those mitochondrial defects [106]. Similarly, Paidi and colleagues [107] observed that the cognitive defects observed in icvSTZ rats were associated with an increased mitochondrial fragmentation. In monkeys, icvSTZ caused a pronounced ventricular enlargement and parenchymal atrophy, $A \beta$ deposition, hippocampal cell loss, tauopathy, astrogliosis, and microglial activation [108]. The Chinese herbal medicine geniposide ameliorates learning and memory deficits, reduces tau phosphorylation, and decreases apoptosis via GSK3 $\beta$ pathway in icvSTZ rats [109]. Also, the GLP-1 analogue exenatide [110] and intranasal insulin [111] improve cognitive function, attenuate the levels of hyperphosphorylated tau and inflammation, and enhance neurogenesis in icvSTZ rats.

\section{Diabetes/hyperglycemia exacerbate(s) AD (like) pathology}

All the above studies demonstrate that diabetes induces AD-like changes supporting the notion that diabetes increases the risk of developing AD. However, there is also evidence that diabetes exacerbates AD progression.

Early studies from our laboratory [112] showed that brain mitochondria isolated from Goto-Kakizaki rats present an age-related decline of the respiratory chain and oxidative phosphorylation system efficiency and a higher susceptibility to oxidative 
damage; those age-dependent effects being highly exacerbated by the neurotoxic peptides $A \beta_{25-35}$ and $\mathrm{A} \beta_{40}$ [112] and ameliorated by coenzyme Q10 treatment [113]. Also, brain mitochondria isolated from STZ diabetic rats are highly susceptible to $A \beta_{40}$, which cause an impairment of the respiratory chain and phosphorylation system and an increased production of ROS [61]. Interestingly, $A \beta_{40}$-mediated mitochondrial defects were attenuated by insulin treatment [61]. Consistently, brain endothelial cells under chronic hyperglycemia are more susceptible to $\mathrm{A} \beta_{40}$ toxicity, an effect mediated by mitochondrial ROS [114]. In this line, Gou and colleagues [115] observed that chronic hyperglycemia induced via the heterozygous knockout of Pdx1 worsens AD-like neuropathology in mice. Similarly, Hayashi-Park and colleagues [116] reported that diabetes exacerbates neuropathology, but not cognitive dysfunction, of middle-aged 3xTg-AD mice. It was also reported that hyperglycemia exacerbates mitochondrial defects, synaptic injury, and cognitive dysfunction in the brains of transgenic AD mice [63], which suggest that the synergistic interaction between diabetes (hyperglycemia) and $\mathrm{AD}$ on mitochondria may be responsible for brain alterations characteristic of both disorders.

\section{AUTHOR VIEWS AND CONCLUSIONS}

Mitochondria are crucial organelles for life and death of cells. Recent discoveries show that mitochondria have a key role in regulating synaptic transmission, brain function, and cognition in aging [117] and, most probably, age-related disorders such as diabetes (namely T2D) and AD. Although mitochondrial dysfunction affects all organs, the brain appears most vulnerable to mitochondrial defects suggesting that mitochondria regulate fundamental aspects of brain function. With glucose oxidation the most relevant source of energy in the brain, neurons rely almost exclusively on the mitochondrial oxidative phosphorylation system to obtain ATP to fulfill their high energy needs. Since diabetes and AD are characterized by defective brain glucose metabolism, it is not surprising that mitochondrial anomalies are a defect shared by both disorders and that mitochondrial alterations caused by diabetes can contribute to neurodegenerative events such as AD.

As discussed above, a strong body of evidence from our laboratory and others support a mechanistic role for mitochondria in the connection between diabetes and $\mathrm{AD}$ (Fig. 1). However, it remains uncertain whether defective mitochondria are the initiating defect or secondary to altered insulin signaling. As stated above, altered insulin signaling is another mechanistic link between $\mathrm{AD}$ and diabetes. The existing literature shows that both insulin signaling and mitochondria defects can affect each other (Fig. 1). Peng and colleagues [118] observed that neurons exposed to high glucose develop mitochondrial defects, which affect 5' AMP-activated protein kinase (AMPK)/AKT signaling contributing to insulin resistance. It was also shown that resveratrol, which activates peroxisome proliferator-activated receptor $\gamma$ coactivator $1 \alpha$ (PGC- $1 \alpha)$ that stimulates mitochondrial function $[119,120]$, improves AMPK/AKT signaling increasing insulin sensitivity [118]. In skeletal muscle and liver mitochondrial dysfunction and ROS overproduction activate c-Jun N-terminal kinase (JNK) leading to insulin resistance [121]. A similar process can occur in the brain since JNK activation has been observed in $\mathrm{AD}[62,122,123]$.

However, insulin resistance can also affect mitochondrial function. Previous studies showed that pancreatic $\beta$-cells from $\beta$-cell specific insulin receptor knockout ( $\beta$ IRKO) mice [124] and the deletion of insulin receptors in mice cardiomyocytes (CIRKO mice) cause mitochondrial dysfunction [125]. Furthermore, prolonged exposure to insulin affects mitochondrial DNA (mtDNA), biogenesis and mass, and ATP content in hepatocytes due to a decrease in the levels of both nuclear respiratory factor (NRF) and mitochondrial transcription factor A (Tfam) [126]. Insulin also modulates mitochondrial biogenesis through the mammalian target of rapamycin (mTOR)-dependent regulation of PGC1- $\alpha$, a master regulator of mitochondrial biogenesis responsible for the co-activation of several metabolically significant nuclear and non-nuclear receptor transcription factors such as NRF 1 and 2 [127, 128]. In addition, thiazolidinediones, clinically used to ameliorate insulin resistance in T2D, increase mitochondrial biogenesis in human subcutaneous adipose tissue, human neuronal NT2 cells, and mouse brain [129-131], which suggest that insulin modulates mitochondria.

In conclusion, although mitochondrial defects, particularly those associated with diabetes, seem to play an important and early role in AD development, further studies are needed to clarify if those defects can be the triggers or secondary events. This is of utmost importance since diabetes and AD have become global epidemics and no effective treatments exist for AD. Importantly, we must keep in mind that 


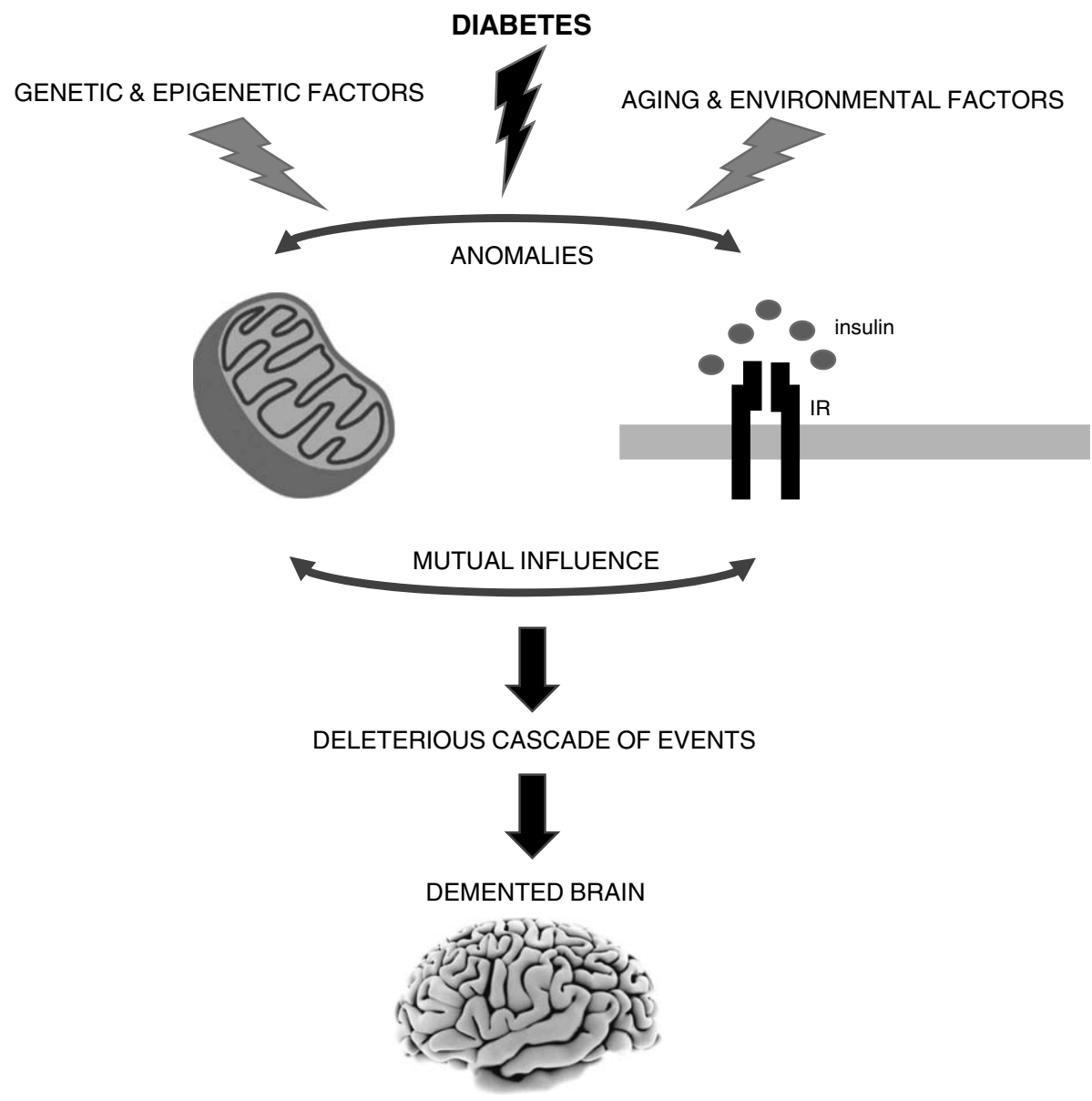

Fig. 1. The brain is highly vulnerable to mitochondrial defects since neurons rely almost exclusively in the mitochondrial oxidative phosphorylation system to obtain ATP to fulfill their high energy needs. Accumulating evidence shows that mitochondrial alterations caused by diabetes can contribute to neurodegenerative events such as Alzheimer's disease (AD). However, it remains uncertain whether defective mitochondria are the initiating defect or secondary to altered insulin signaling. In fact, both insulin signaling and mitochondria defects can affect each other. It is also important to note that sporadic AD is a multifactorial condition that depends on the complex interplay between environmental, genetic and epigenetic factors. IR, insulin receptor.

(sporadic) $\mathrm{AD}$ is a multifactorial condition and that depending on the complex interplay between environmental, genetic, and epigenetic factors, it may have distinct or even multiple triggers (Fig. 1).

\section{ACKNOWLEDGMENTS}

This work was financed by the European Regional Development Fund (ERDF), through the Centro 2020 Regional Operational Program: project CENTRO01-0145-FEDER-000012-HealthyAging2020, the COMPETE 2020 - Operational Program for Competitiveness and Internationalization, and the Portuguese national funds via FCT - Fundação para a Ciência e a Tecnologia, I.P.: project POCI01-0145-FEDER-007440.
The author's disclosure is available online (https:// www.j-alz.com/manuscript-disclosures/17-0931r1).

\section{REFERENCES}

[1] Mattson MP, Gleichmann M, Cheng A (2008) Mitochondria in neuroplasticity and neurological disorders. Neuron 60, 748-766.

[2] Fontán-Lozano A, López-Lluch G, Delgado-García JM, Navas P, Carrión AM (2008) Molecular bases of caloric restriction regulation of neuronal synaptic plasticity. $\mathrm{Mol}$ Neurobiol 38, 167-177.

[3] Moreira PI, Carvalho C, Zhu X, Smith MA, Perry G (2010) Mitochondrial dysfunction is a trigger of Alzheimer's disease pathophysiology. Biochim Biophys Acta 1802, 2-10.

[4] Correia SC, Perry G, Moreira PI (2016) Mitochondrial traffic jams in Alzheimer's disease-pinpointing the roadblocks. Biochim Biophys Acta 1862, 1909-1917. 
[5] Cardoso S, Carvalho C, Correia SC, Seiça RM, Moreira PI (2016) Alzheimer's disease: From mitochondrial perturbations to mitochondrial medicine. Brain Pathol 26, 632-647.

[6] Cardoso S, Seiça RM, Moreira PI (2017) Mitochondria as a target for neuroprotection: Implications for Alzheimer's disease. Expert Rev Neurother 17, 77-91.

[7] Cardoso SM, Correia SC, Carvalho C, Moreira PI (2017) Mitochondria in Alzheimer's disease and diabetesassociated neurodegeneration: License to heal! Handb Exp Pharmacol 240, 281-308.

[8] Bhatti JS, Bhatti GK, Reddy PH (2017) Mitochondrial dysfunction and oxidative stress in metabolic disorders A step towards mitochondria based therapeutic strategies. Biochim Biophys Acta 1863, 1066-1077.

[9] Forbes JM, Cooper ME (2013) Mechanisms of diabetic complications. Physiol Rev 93, 137-188.

[10] Biessels GJ, Kappelle AC, Bravenboer B, Erkelens DW, Gispen WH (1994) Cerebral function in diabetes mellitus. Diabetologia 37, 643-650.

[11] Fried PJ, Schilberg L, Brem AK, Saxena S, Wong B, Cypess AM, Horton ES, Pascual-Leone A (2017) Humans with Type-2 diabetes show abnormal long-term potentiation-like cortical plasticity associated with verbal learning deficits. J Alzheimers Dis 55, 89-100.

[12] Seaquist ER (2015) The impact of diabetes on cerebral structure and function. Psychosom Med 77, 616-621.

[13] van Duinkerken E, Schoonheim MM, Steenwijk MD, Klein M, IJzerman RG, Moll AC, Heymans MW, Snoek FJ, Barkhof F, Diamant M (2014) Ventral striatum, but not cortical volume loss, is related to cognitive dysfunction in type 1 diabetic patients with and without microangiopathy. Diabetes Care 37, 2483-2490.

[14] Nunley KA, Rosano C, Ryan CM, Jennings JR, Aizenstein HJ, Zgibor JC, Costacou T, Boudreau RM, Miller R, Orchard TJ, Saxton JA (2015) Clinically relevant cognitive impairment in middle-aged adults with childhood-onset type 1 diabetes. Diabetes Care 38, 1768-1776.

[15] Macpherson H, Formica M, Harris E, Daly RM (2017) Brain functional alterations in Type 2 Diabetes - A systematic review of fMRI studies. Front Neuroendocrinol 47, 34-46.

[16] Simó R, Ciudin A, Simó-Servat O, Hernández C (2017) Cognitive impairment and dementia: A new emerging complication of type 2 diabetes - The diabetologist's perspective. Acta Diabetol 54, 417-424.

[17] Smolina K, Wotton CJ, Goldacre MJ (2015) Risk of dementia in patients hospitalised with type 1 and type 2 diabetes in England, 1998-2011: A retrospective national record linkage cohort study. Diabetologia 58, 942-950.

[18] Ristow M (2004) Neurodegenerative disorders associated with diabetes mellitus. J Mol Med (Berl) 82, 510-529.

[19] Xu W, Qiu C, Gatz M, Pedersen NL, Johansson B, Fratiglioni L (2009) Mid- and late-life diabetes in relation to the risk of dementia: A population-based twin study. Diabetes 58, 71-77.

[20] Aviles-Olmos I, Limousin P, Lees A, Foltynie T (2013) Parkinson's disease, insulin resistance and novel agents of neuroprotection. Brain 136, 374-384.

[21] Lalić NM, Marić J, Svetel M, Jotić A, Stefanova E, Lalić K, Dragasević N, Milicić T, Lukić L, Kostić VS (2008) Glucose homeostasis in Huntington disease: Abnormalities in insulin sensitivity and early-phase insulin secretion. Arch Neurol 65, 476-480.
[22] Moreira PI (2012) Alzheimer's disease and diabetes: An integrative view of the role of mitochondria, oxidative stress, and insulin. J Alzheimers Dis 30, S199-215.

[23] Moreira PI, Santos MS, Seiça R, Oliveira CR (2007) Brain mitochondrial dysfunction as a link between Alzheimer's disease and diabetes. J Neurol Sci 257, 206-214.

[24] Miles WR, Root HF (1992) Psychologic tests applied to diabetic patients. Arch Intern Med 30, 767-777.

[25] Dejong R (1950) The nervous system complications of diabetes mellitus, with special reference to cerebrovascular changes. J Nerv Ment Dis 111, 181-206.

[26] Ryan CM, Geckle MO, Orchard TJ (2003) Cognitive efficiency declines over time in adults with Type 1 diabetes: Effects of micro- and macrovascular complications. Diabetologia 46, 940-948.

[27] Diabetes Control and Complications Trial/Epidemiology of Diabetes Interventions and Complications Study Research Group, Jacobson AM, Musen G, Ryan CM, Silvers N, Cleary P, Waberski B, Burwood A, Weinger K, Bayless M, Dahms W, Harth J (2007) Long-term effect of diabetes and its treatment on cognitive function. $N$ Engl $J$ Med 356, 1842-1852.

[28] Perantie DC, Lim A, Wu J, Weaver P, Warren SL, Sadler M, White NH, Hershey T (2008) Effects of prior hypoglycemia and hyperglycemia on cognition in children with type 1 diabetes mellitus. Pediatric Diabetes 9, 87-95.

[29] Kanaya AM, Barrett-Connor E, Gildengorin G, Yaffe K (2004) Change in cognitive function by glucose tolerance status in older adults: A 4-year prospective study of the Rancho Bernardo study cohort. Arch Intern Med 164, 1327-1333.

[30] Manschot SM, Brands AM, van der Grond J, Kessels RP, Algra A, Kappelle LJ, Biessels GJ, Utrecht Diabetic Encephalopathy Study Group (2006) Brain magnetic resonance imaging correlates of impaired cognition in patients with type 2 diabetes. Diabetes 55, 1106-1113.

[31] Ebady SA, Arami MA, Shafigh MH (2009) Investigation on the relationship between diabetes mellitus type 2 and cognitive impairment. Diabetes Res Clin Pract 82, 305309.

[32] van den Berg E, Kloppenborg RP, Kessels RP, Kappelle LJ, Biessels GJ (2009) Type 2 diabetes mellitus, hypertension, dyslipidemia and obesity: A systematic comparison of their impact on cognition. Biochim Biophys Acta 1792, 470-481.

[33] Biessels GJ, Staekenborg S, Brunner E, Brayne C, Scheltens P (2006) Risk of dementia in diabetes mellitus: A systematic review. Lancet Neurol 5, 64-74.

[34] Ott A, Stolk RP, Hofman A, van Harskamp F, Grobbee DE, Breteler MM (1996) Association of diabetes mellitus and dementia: The Rotterdam Study. Diabetologia 39, 13921397.

[35] Ott A, Stolk RP, van Harskamp F, Pols HA, Hofman A, Breteler MM (1999) Diabetes mellitus and the risk of dementia: The Rotterdam Study. Neurology 53, 1937 1942.

[36] Ahtiluoto S, Polvikoski T, Peltonen M, Solomon A, Tuomilehto J, Winblad B, Sulkava R, Kivipelto M (2010) Diabetes, Alzheimer disease, and vascular dementia: A population-based neuropathologic study. Neurology 75, 1195-1202.

[37] Cheng D, Noble J, Tang MX, Schupf N, Mayeux R, Luchsinger JA (2011) Type 2 diabetes and late-onset Alzheimer's disease. Dement Geriatr Cogn Disord 31, 424-430. 
[38] Irie F, Fitzpatrick AL, Lopez OL, Kuller LH, Peila R, Newman AB, Launer LJ (2008) Enhanced risk for Alzheimer disease in persons with type 2 diabetes and APOE epsilon4: The Cardiovascular Health Study Cognition Study. Arch Neurol 65, 89-93.

[39] Rastas S, Pirttilä T, Mattila K, Verkkoniemi A, Juva K, Niinistö L, Länsimies E, Sulkava R (2010) Vascular risk factors and dementia in the general population aged $>85$ years: Prospective population-based study. Neurobiol Aging 31, 1-7.

[40] Schnaider Beeri M, Goldbourt U, Silverman JM, Noy S, Schmeidler J, Ravona-Springer R, Sverdlick A, Davidson M (2004) Diabetes mellitus in midlife and the risk of dementia three decades later. Neurology 63, 1902-1907.

[41] Hitmer RA, Sidney S, Selby J, Johnston SC, Yaffe K (2005) Midlife cardiovascular risk factors and risk of dementia in late life. Neurology 64, 277-281.

[42] Xu W, Qiu C, Gatz M, Pedersen NL, Johansson B, Fratiglioni L (2009) Mid- and late-life diabetes in relation to the risk of dementia: A population-based twin study. Diabetes 58, 71-77.

[43] Peila R, Rodriguez BL, Launer LJ, Honolulu-Asia Aging Study (2002) Type 2 diabetes, APOE gene, and the risk for dementia and related pathologies: The Honolulu-Asia Aging Study. Diabetes 51, 1256-1262.

[44] Janson J, Laedtke T, Parisi JE, O'Brien P, Petersen RC, Butler PC (2004) Increased risk of type 2 diabetes in Alzheimer disease. Diabetes 53, 474-481.

[45] Hassing LB, Johansson B, Nilsson SE, Berg S, Pedersen NL, Gatz M, McClearn G (2002) Diabetes mellitus is a risk factor for vascular dementia, but not for Alzheimer's disease: A population-based study of the oldest old. Int Psychogeriatr 14, 239-248.

[46] MacKnight C, Rockwood K, Awalt E, McDowell I (2002) Diabetes mellitus and the risk of dementia, Alzheimer's disease and vascular cognitive impairment in the Canadian Study of Health and Aging. Dement Geriatr Cogn Disord 14, 77-83.

[47] Akomolafe A, Beiser A, Meigs JB, Au R, Green RC, Farrer LA, Wolf PA, Seshadri S (2006) Diabetes mellitus and risk of developing Alzheimer disease: Results from the Framingham Study. Arch Neurol 63, 1551-1555.

[48] Reger MA, Watson GS, Green PS, Wilkinson CW, Baker LD, Cholerton B, Fishel MA, Plymate SR, Breitner JC, DeGroodt W, Mehta P, Craft S (2008) Intranasal insulin improves cognition and modulates beta-amyloid in early AD. Neurology 70, 440-448.

[49] Craft S, Baker LD, Montine TJ, Minoshima S, Watson GS, Claxton A, Arbuckle M, Callaghan M, Tsai E, Plymate SR, Green PS, Leverenz J, Cross D, Gerton B (2012) Intranasal insulin therapy for Alzheimer disease and amnestic mild cognitive impairment: A pilot clinical trial. Arch Neurol 69, 29-38.

[50] Claxton A, Baker LD, Hanson A, Trittschuh EH, Cholerton B, Morgan A, Callaghan M, Arbuckle M, Behl C, Craft $S$ (2015) Long-acting intranasal insulin detemir improves cognition for adults with mild cognitive impairment or early-stage Alzheimer's disease dementia. J Alzheimers Dis 44, 897-906.

[51] Reger MA, Watson GS, Frey WH 2nd, Baker LD, Cholerton B, Keeling ML, Belongia DA, Fishel MA, Plymate SR, Schellenberg GD, Cherrier MM, Craft S (2006) Effects of intranasal insulin on cognition in memory-impaired older adults: Modulation by APOE genotype. Neurobiol Aging 27, 451-458
[52] Ng TP, Feng L, Yap KB, Lee TS, Tan CH, Winblad B (2014) Long-term metformin usage and cognitive function among older adults with diabetes. J Alzheimers Dis 41, 61-68.

[53] Moreira PI (2014) Metformin in the diabetic brain: Friend or foe? Ann Transl Med 2, 54.

[54] Tzimopoulou S, Cunningham VJ, Nichols TE, Searle G, Bird NP, Mistry P, Dixon IJ, Hallett WA, Whitcher B, Brown AP, Zvartau-Hind M, Lotay N, Lai RY, Castiglia M, Jeter B, Matthews JC, Chen K, Bandy D, Reiman EM, Gold M, Rabiner EA, Matthews PM (2006) A multicenter randomized proof-of-concept clinical trial applying $\left[{ }^{18} \mathrm{~F}\right]$ FDG-PET for evaluation of metabolic therapy with rosiglitazone XR in mild to moderate Alzheimer's disease. J Alzheimers Dis 22, 1241-1256.

[55] Risner ME, Saunders AM, Altman JF, Ormandy GC, Craft S, Foley IM, Zvartau-Hind ME, Hosford DA, Roses AD, Rosiglitazone in Alzheimer's Disease Study Group (2006) Efficacy of rosiglitazone in a genetically defined population with mild-to-moderate Alzheimer's disease. Pharmacogenomics J 6, 246-254.

[56] Liu J, Wang LN, Jia JP (2015) Peroxisome proliferatoractivated receptor-gamma agonists for Alzheimer's disease and amnestic mild cognitive impairment: A systematic review and meta-analysis. Drugs Aging 32, 57-65.

[57] Lu CH, Yang CY, Li CY, Hsieh CY, Ou HT (2017) Lower risk of dementia with pioglitazone, compared with other second-line treatments, in metformin-based dual therapy: A population-based longitudinal study. Diabetologia. doi: 10.1007/s00125-017-4499-5

[58] Isik AT, Soysal P, Yay A, Usarel C (2017) The effects of sitagliptin, a DPP-4 inhibitor, on cognitive functions in elderly diabetic patients with or without Alzheimer's disease. Diabetes Res Clin Pract 123, 192-198.

[59] Gejl M, Gjedde A, Egefjord L, Møller A, Hansen SB, Vang K, Rodell A, Brændgaard H, Gottrup H, Schacht A, Møller N, Brock B, Rungby J (2016) In Alzheimer's disease, 6-month treatment with GLP-1 analog prevents decline of brain glucose metabolism: Randomized, placebo-controlled, double-blind clinical trial. Front Aging Neurosci 8, 108.

[60] Sebastião I, Candeias E, Santos MS, de Oliveira CR, Moreira PI, Duarte AI (2014) Insulin as a bridge between type 2 diabetes and Alzheimer disease - how anti-diabetics could be a solution for dementia. Front Endocrinol (Lausanne) $\mathbf{5}, 110$.

[61] Moreira PI, Santos MS, Sena C, Seiça R, Oliveira CR (2005) Insulin protects against amyloid beta-peptide toxicity in brain mitochondria of diabetic rats. Neurobiol Dis 18, 628-637.

[62] De Felice FG, Ferreira ST (2014) Inflammation, defective insulin signaling, and mitochondrial dysfunction as common molecular denominators connecting type 2 diabetes to Alzheimer disease. Diabetes 63, 2262-2272.

[63] Wang Y, Wu L, Li J, Fang D, Zhong C, Chen JX, Yan SS (2015) Synergistic exacerbation of mitochondrial and synaptic dysfunction and resultant learning and memory deficit in a mouse model of diabetic Alzheimer's disease. J Alzheimers Dis 43, 451-463.

[64] Mastrocola R, Restivo F, Vercellinatto I, Danni O, Brignardello E, Aragno M, Boccuzzi G (2005) Oxidative and nitrosative stress in brain mitochondria of diabetic rats. J Endocrinol 187, 37-44.

[65] Zhou Y, Luo Y, Dai J (2013) Axonal and dendritic changes are associated with diabetic encephalopathy in rats: An 
important risk factor for Alzheimer's disease. J Alzheimers Dis 34, 937-947.

[66] Solanki I, Parihar P, Shetty R, Parihar MS (2017) Synaptosomal and mitochondrial oxidative damage followed by behavioral impairments in streptozotocin induced diabetes mellitus: Restoration by Malvastrum tricuspidatum. Cell Mol Biol (Noisy-le-grand) 63, 94-101.

[67] Qu Z, Jiao Z, Sun X, Zhao Y, Ren J, Xu G (2011) Effects of streptozotocin-induced diabetes on tau phosphorylation in the rat brain. Brain Res 1383, 300-306.

[68] Kim DY, Jung SY, Kim TW, Lee KS, Kim K (2015) Treadmill exercise decreases incidence of Alzheimer's disease by suppressing glycogen synthase kinase- $3 \beta$ expression in streptozotocin-induced diabetic rats. J Exerc Rehabil 11, 87-94.

[69] Currais A, Prior M, Lo D, Jolivalt C, Schubert D, Maher P (2012) Diabetes exacerbates amyloid and neurovascular pathology in aging-accelerated mice. Aging Cell 11, 10171026.

[70] Liu LP, Yan TH, Jiang LY, Hu W, Hu M, Wang C, Zhang Q, Long Y, Wang JQ, Li YQ, Hu M, Hong H (2013) Pioglitazone ameliorates memory deficits in streptozotocin-induced diabetic mice by reducing brain $\beta$ amyloid through PPAR $\gamma$ activation. Acta Pharmacol Sin 34, 455-463.

[71] Zou W, Yuan J, Tang ZJ, Wei HJ, Zhu WW, Zhang P, Gu HF, Wang CY, Tang XQ (2017) Hydrogen sulfide ameliorates cognitive dysfunction in streptozotocin-induced diabetic rats: Involving suppression in hippocampal endoplasmic reticulum stress. Oncotarget 8, 64203-64216.

[72] Zheng H, Lin Q, Wang D, Xu P, Zhao L, Hu W, Bai G, Yan Z, Gao H (2017) NMR-based metabolomics reveals brain region-specific metabolic alterations in streptozotocininduced diabetic rats with cognitive dysfunction. Metab Brain Dis 32, 585-593.

[73] Santos RX, Correia SC, Alves MG, Oliveira PF, Cardoso S, Carvalho C, Duarte AI, Santos MS, Moreira PI (2014) Insulin therapy modulates mitochondrial dynamics and biogenesis, autophagy and tau protein phosphorylation in the brain of type 1 diabetic rats. Biochim Biophys Acta 1842, 1154-1166.

[74] Strachan MW, Deary IJ, Ewing FM, Frier BM (2000) Recovery of cognitive function and mood after severe hypoglycemia in adults with insulin-treated diabetes. Diabetes Care 23, 305-312.

[75] Schultes B, Kern W, Oltmanns K, Peters A, Gais S, Fehm HL, Born J (2005) Differential adaptation of neurocognitive brain functions to recurrent hypoglycemia in healthy men. Psychoneuroendocrinology 30, 149-161.

[76] Cardoso S, Correia SC, Santos RX, Carvalho C, Candeias E, Duarte AI, Plácido AI, Santos MS, Moreira PI (2013) Hyperglycemia, hypoglycemia and dementia: Role of mitochondria and uncoupling proteins. Curr Mol Med 13, 586-601.

[77] McGowan JE, Chen L, Gao D, Trush M, Wei C (2006) Increased mitochondrial reactive oxygen species production in newborn brain during hypoglycemia. Neurosci Lett 399, 111-114.

[78] Pelligrino DA, Becker GL, Miletich DJ, Albrecht RF (1989) Cerebral mitochondrial respiration in diabetic and chronically hypoglycemic rats. Brain Res 479, 241-246.

[79] Cardoso S, Santos MS, Seiça R, Moreira PI (2010) Cortical and hippocampal mitochondria bioenergetics and oxidative status during hyperglycemia and/or insulin-induced hypoglycemia. Biochim Biophys Acta 1802, 942-951.
[80] Cardoso S, Carvalho C, Santos R, Correia S, Santos MS, Seiça R, Oliveira CR, Moreira PI (2011) Impact of STZ-induced hyperglycemia and insulin-induced hypoglycemia in plasma amino acids and cortical synaptosomal neurotransmitters. Synapse 65, 457-466.

[81] Cardoso S, Santos RX, Correia SC, Carvalho C, Santos MS, Baldeiras I, Oliveira CR, Moreira PI (2013) Insulininduced recurrent hypoglycemia exacerbates diabetic brain mitochondrial dysfunction and oxidative imbalance. Neurobiol Dis 49, 1-12.

[82] Dave KR, Tamariz J, Desai KM, Brand FJ, Liu A, Saul I, Bhattacharya SK, Pileggi A (2011) Recurrent hypoglycemia exacerbates cerebral ischemic damage in streptozotocin-induced diabetic rats. Stroke 42, 14041411.

[83] Bechmann I, Diano S, Warden CH, Bartfai T, Nitsch R, Horvath TL (2002) Brain mitochondrial uncoupling protein 2(UCP2): A protective stress signal in neuronal injury. Biochem Pharmacol 64, 363-367.

[84] Cardoso S, Correia S, Carvalho C, Candeias E, Plácido AI, Duarte AI, Seiça RM, Moreira PI (2015) Perspectives on mitochondrial uncoupling proteins-mediated neuroprotection. J Bioenerg Biomembr 47, 119-131.

[85] Cardoso S, Santos MS, Moreno A, Moreira PI (2013) UCP2 and ANT differently modulate proton-leak in brain mitochondria of long-term hyperglycemic and recurrent hypoglycemic rats. J Bioenerg Biomembr $\mathbf{4 5}$, 397-407.

[86] Cardoso S, Seiça RM, Moreira PI (2018) Uncoupling protein 2 inhibition exacerbates glucose fluctuation-mediated neuronal effects. Neurotox Res 33, 388-401.

[87] Rudofsky G Jr, Schroedter A, Schlotterer A, Voron'ko OE, Schlimme M, Tafel J, Isermann BH, Humpert PM, Morcos M, Bierhaus A, Nawroth PP, Hamann A (2006) Functional polymorphisms of UCP2 and UCP3 are associated with a reduced prevalence of diabetic neuropathy in patients with type 1 diabetes. Diabetes Care 29, 89-94.

[88] Raza H, John A, Howarth FC (2015) Increased oxidative stress and mitochondrial dysfunction in zucker diabetic rat liver and brain. Cell Physiol Biochem 35, 1241-1251.

[89] Carvalho C, Correia SC, Santos MS, Baldeiras I, Oliveira CR, Seica R, Moreira PI (2014) Vascular, oxidative, and synaptosomal abnormalities during aging and the progression of type 2 diabetes. Curr Neurovasc Res 11, 330-339.

[90] Carvalho C, Cardoso S, Correia SC, Santos RX, Santos MS, Baldeiras I, Oliveira CR, Moreira PI (2012) Metabolic alterations induced by sucrose intake and Alzheimer's disease promote similar brain mitochondrial abnormalities. Diabetes 61, 1234-1242.

[91] Carvalho C, Machado N, Mota PC, Correia SC, Cardoso S, Santos RX, Santos MS, Oliveira CR, Moreira PI (2013) Type 2 diabetic and Alzheimer's disease mice present similar behavioral, cognitive, and vascular anomalies. J Alzheimers Dis 35, 623-635.

[92] Carvalho C, Santos MS, Oliveira CR, Moreira PI (2015) Alzheimer's disease and type 2 diabetes-related alterations in brain mitochondria, autophagy and synaptic markers. Biochim Biophys Acta 1852, 1665-1675.

[93] Sena CM, Pereira AM, Carvalho C, Fernandes R, Seiça RM, Oliveira CR, Moreira PI (2015) Type 2 diabetes aggravates Alzheimer's disease-associated vascular alterations of the aorta in mice. J Alzheimers Dis 45, 127-138.

[94] Huang S, Wang Y, Gan X, Fang D, Zhong C, Wu L, Hu G, Sosunov AA, McKhann GM, Yu H, Yan SS (2015) 
Drp1-mediated mitochondrial abnormalities link to synaptic injury in diabetes model. Diabetes 64, 1728-1742.

[95] Akhtar MW, Sanz-Blasco S, Dolatabadi N, Parker J, Chon K, Lee MS, Soussou W, McKercher SR, Ambasudhan R, Nakamura T, Lipton SA (2016) Elevated glucose and oligomeric $\beta$-amyloid disrupt synapses via a common pathway of aberrant protein S-nitrosylation. Nat Commun 7, 10242.

[96] Petrov D, Pedrós I, Artiach G, Sureda FX, Barroso E, Pallás M, Casadesús G, Beas-Zarate C, Carro E, Ferrer I, Vazquez-Carrera M, Folch J, Camins A (2015) High-fat diet-induced deregulation of hippocampal insulin signaling and mitochondrial homeostasis deficiences contribute to Alzheimer disease pathology in rodents. Biochim Biophys Acta 1852, 1687-1699.

[97] Pintana H, Apaijai N, Chattipakorn N, Chattipakorn SC (2013) DPP-4 inhibitors improve cognition and brain mitochondrial function of insulin-resistant rats. $J$ Endocrinol 218, 1-11.

[98] Pintana H, Apaijai N, Pratchayasakul W, Chattipakorn N, Chattipakorn SC (2012) Effects of metformin on learning and memory behaviors and brain mitochondrial functions in high fat diet induced insulin resistant rats. Life Sci 91, 409-414.

[99] Yang Y, Ma D, Xu W, Chen F, Du T, Yue W, Shao S, Yuan G (2016) Exendin-4 reduces tau hyperphosphorylation in type 2 diabetic rats via increasing brain insulin level. $\mathrm{Mol}$ Cell Neurosci 70, 68-75.

[100] Xu W, Yang Y, Yuan G, Zhu W, Ma D, Hu S (2015) Exendin-4, a glucagon-like peptide-1 receptor agonist, reduces Alzheimer disease-associated tau hyperphosphorylation in the hippocampus of rats with type 2 diabetes. J Investig Med 63, 267-272.

[101] Yang Y, Ma D, Xu W, Chen F, Du T, Yue W, Shao S, Yuan G (2016) Exendin-4 reduces tau hyperphosphorylation in type 2 diabetic rats via increasing brain insulin level. $\mathrm{Mol}$ Cell Neurosci 70, 68-75.

[102] Candeias E, Sebastião I, Cardoso S, Carvalho C, Santos MS, Oliveira CR, Moreira PI, Duarte AI (2017) Brain GLP-1/IGF-1 signaling and autophagy mediate exendin-4 protection against apoptosis in type 2 diabetic rats. $\mathrm{Mol}$ Neurobiol. doi: 10.1007/s12035-017-0622-3

[103] Lannert H, Hoyer S (1998) Intracerebroventricular administration of streptozotocin causes long-term diminutions in learning and memory abilities and in cerebral energy metabolism in adult rats. Behav Neurosci 112, 1199-1208.

[104] Grünblatt E, Salkovic-Petrisic M, Osmanovic J, Riederer $\mathrm{P}$, Hoyer S (2007) Brain insulin system dysfunction in streptozotocin intracerebroventricularly treated rats generates hyperphosphorylated tau protein. J Neurochem $\mathbf{1 0 1}$, 757-770.

[105] Salkovic-Petrisic M, Osmanovic-Barilar J, Brückner MK, Hoyer S, Arendt T, Riederer P (2011) Cerebral amyloid angiopathy in streptozotocin rat model of sporadic Alzheimer's disease: A long-term follow up study. $\mathrm{J} \mathrm{Neu}$ ral Transm (Vienna) 118, 765-772.

[106] Correia SC, Santos RX, Santos MS, Casadesus G, Lamanna JC, Perry G, Smith MA, Moreira PI (2013) Mitochondrial abnormalities in a streptozotocin-induced rat model of sporadic Alzheimer's disease. Curr Alzheimer Res 10, 406-419.

[107] Paidi RK, Nthenge-Ngumbau DN, Singh R, Kankanala T, Mehta H, Mohanakumar KP (2015) Mitochondrial deficits accompany cognitive decline following single bilateral intracerebroventricular streptozotocin. Curr Alzheimer Res 12, 785-795.

[108] Yeo HG, Lee Y, Jeon CY, Jeong KJ, Jin YB, Kang P, Kim SU, Kim JS, Huh JW, Kim YH, Sim BW, Song BS, Park YH, Hong Y, Lee SR, Chang KT (2015) Characterization of cerebral damage in a monkey model of Alzheimer's disease induced by intracerebroventricular injection of streptozotocin. J Alzheimers Dis 46, 989-1005.

[109] Gao C, Liu Y, Jiang Y, Ding J, Li L (2014) Geniposide ameliorates learning memory deficits, reduces tau phosphorylation and decreases apoptosis via GSK3 $\beta$ pathway in streptozotocin-induced alzheimer rat model. Brain Pathol 24, 261-269.

[110] Solmaz V, Çinar BP, Yiğittürk G, Çavuşoğlu T, Taşkiran D, Erbaş O (2015) Exenatide reduces TNF- $\alpha$ expression and improves hippocampal neuron numbers and memory in streptozotocin treated rats. Eur J Pharmacol 765, 482-487.

[111] Guo Z, Chen Y, Mao YF, Zheng T, Jiang Y, Yan Y, Yin X, Zhang B (2017) Long-term treatment with intranasal insulin ameliorates cognitive impairment, tau hyperphosphorylation, and microglial activation in a streptozotocin-induced Alzheimer's rat model. Sci Rep 7, 45971.

[112] Moreira PI, Santos MS, Moreno AM, Seiça R, Oliveira CR (2003) Increased vulnerability of brain mitochondria in diabetic (Goto-Kakizaki) rats with aging and amyloid-beta exposure. Diabetes 52, 1449-1456.

[113] Moreira PI, Santos MS, Sena C, Nunes E, Seiça R, Oliveira CR (2005) CoQ10 therapy attenuates amyloid beta-peptide toxicity in brain mitochondria isolated from aged diabetic rats. Exp Neurol 196, 112-119.

[114] Carvalho C, Katz PS, Dutta S, Katakam PV, Moreira PI, Busija DW (2014) Increased susceptibility to amyloid- $\beta$ toxicity in rat brain microvascular endothelial cells under hyperglycemic conditions. J Alzheimers Dis 38, 75-83.

[115] Guo C, Zhang S, Li JY, Ding C, Yang ZH, Chai R, Wang X, Wang ZY (2016) Chronic hyperglycemia induced via the heterozygous knockout of Pdx1 worsens neuropathological lesion in an Alzheimer mouse model. Sci Rep 6, 29396.

[116] Hayashi-Park E, Ozment BN, Griffith CM, Zhang H, Patrylo PR, Rose GM (2017) Experimentally induced diabetes worsens neuropathology, but not learning and memory, in middle aged 3xTg mice. Behav Brain Res 322, 280-287.

[117] Hara Y, Yuk F, Puri R, Janssen WG, Rapp PR, Morrison JH (2014) Presynaptic mitochondrial morphology in monkey prefrontal cortex correlates with working memory and is improved with estrogen treatment. Proc Natl Acad Sci U S A 111, 486-491.

[118] Peng Y, Liu J, Shi L, Tang Y, Gao D, Long J, Liu J (2016) Mitochondrial dysfunction precedes depression of AMPK/AKT signaling in insulin resistance induced by high glucose in primary cortical neurons. $J$ Neurochem 137, 701-713.

[119] Bitterman JL, Chung JH (2015) Metabolic effects of resveratrol: Addressing the controversies. Cell Mol Life Sci 72, 1473-1488.

[120] Burkewitz K, Zhang Y, Mair WB (2014) AMPK at the nexus of energetics and aging. Cell Metab 20, 10-25.

[121] Sebastián D, Hernández-Alvarez MI, Segalés J, Sorianello E, Muñoz JP, Sala D, Waget A, Liesa M, Paz JC, Gopalacharyulu P, Orešič M, Pich S, Burcelin R, Palacín M, Zorzano A (2012) Mitofusin 2 (Mfn2) links mitochondrial and endoplasmic reticulum function with insulin 
signaling and is essential for normal glucose homeostasis. Proc Natl Acad Sci U S A 109, 5523-5528.

[122] Talbot K, Wang HY, Kazi H, Han LY, Bakshi KP, Stucky A, Fuino RL, Kawaguchi KR, Samoyedny AJ, Wilson RS, Arvanitakis Z, Schneider JA, Wolf BA, Bennett DA, Trojanowski JQ, Arnold SE (2012) Demonstrated brain insulin resistance in Alzheimer's disease patients is associated with IGF-1 resistance, IRS-1 dysregulation, and cognitive decline. J Clin Invest 122, 1316-1338.

[123] Bomfim TR, Forny-Germano L, Sathler LB, BritoMoreira J, Houzel JC, Decker H, Silverman MA, Kazi H, Melo HM, McClean PL, Holscher C, Arnold SE, Talbot K, Klein WL, Munoz DP, Ferreira ST, De Felice FG (2012) An anti-diabetes agent protects the mouse brain from defective insulin signaling caused by Alzheimer's disease- associated Abeta oligomers. J Clin Invest 122, 1339-1353.

[124] Liu S, Okada T, Assmann A, Soto J, Liew CW, Bugger H, Shirihai OS, Abel ED, Kulkarni RN (2009) Insulin signaling regulates mitochondrial function in pancreatic beta-cells. PLoS One 4, e7983.

[125] Boudina S, Bugger H, Sena S, O'Neill BT, Zaha VG, Ilkun O, Wright JJ, Mazumder PK, Palfreyman E, Tidwell TJ, Theobald H, Khalimonchuk O, Wayment B, Sheng X, Rodnick KJ, Centini R, Chen D, Litwin SE, Weimer BE, Abel ED (2009) Contribution of impaired myocardial insulin signaling to mitochondrial dysfunction and oxidative stress in the heart. Circulation 119, 1272-1283.

[126] Liu HY, Yehuda-Shnaidman E, Hong T, Han J, Pi J, Liu Z, Cao W (2009) Prolonged exposure to insulin suppresses mitochondrial production in primary hepatocytes. $J$ Biol Chem 284, 14087-14095.

[127] Finck BN, Kelly DP (2006) PGC-1 coactivators: Inducible regulators of energy metabolism in health and disease. J Clin Invest 116, 615-622.

[128] Hardie DG (2007) AMP-activated/SNF1 protein kinases: Conserved guardians of cellular energy. Nat Rev Mol Cell Biol 8, 774-785.

[129] Ghosh S, Patel N, Rahn D, McAllister J, Sadeghi S, Horwitz G, Berry D, Wang KX, Swerdlow RH (2007) The thiazolidinedione pioglitazone alters mitochondrial function in human neuron-like cells. Mol Pharmacol 71, 1695-1702.

[130] Strum JC, Shehee R, Virley D, Richardson J, Mattie M, Selley P, Ghosh S, Nock C, Saunders A, Roses A (2007) Rosiglitazone induces mitochondrial biogenesis in mouse brain. J Alzheimers Dis 11, 45-51.

[131] Bogacka I, Xie H, Bray GA, Smith SR (2005) Pioglitazone induces mitochondrial biogenesis in human subcutaneous adipose tissue in vivo. Diabetes 54, 1392-1399. 